\title{
An Analysis of Relationship between Technological Gap and Socio- economic Characteristics of Arecanut Growers in Uttara Kannada District
}

\author{
Vinoda Shankara Naik ${ }^{1 *}$ and S.L. Patil ${ }^{2}$ \\ ${ }^{1}$ Department of Agricultural Extension, GKVK, UAS, Bengaluru-560065, India \\ ${ }^{2}$ Department of Agricultural Extension Education, UAS, Dharwad, Karnataka, India \\ *Corresponding author
}

Keywords

Socio-economic characteristics,

Technological gap, Scientific orientation, Market orientation, Multidimensional behavior

Article Info

Accepted:

10 January 2019

Available Online:

10 February 2019

\section{A B S T R A C T}

Socio-economic characteristics of farmers play an important role in adoption of improved agricultural practices. The present study was conducted during 2015-16 in Uttara Kannada district of Karnataka. Sirsi, Siddapur and Yellapur talukas of Uttara Kannada District were selected for the study in the view of their highest share in area and the production in the district. The total sample size was 180 . The ex-post-facto research design was used for the study. The study showed that land holding, extension contact, mass media exposure, economic motivation, scientific orientation, education and market orientation had significant relationship with the technological gap of the arecanut growers. Whereas age, area under arecanut cultivation, experience in arecanut cultivation, family size, annual income, organization participation were non significantly related with technological gap. The regression analysis revealed that the selected independent variables put together explained 56.40 per cent of variation in technological gap of the arecanut growers. So, study concludes that it is essential to understand the multidimensional behavior and socioeconomic characteristics of the farmers for adoption of improved agricultural practices which in turn reduces the technological gap.

\section{Introduction}

The areca nut is not a true nut, but rather a fruit categorized as a berry. It is commercially available in dried, cured, and fresh forms. There is around five lakh tonnes production recorded by arecanut in Karnataka. Demand for arecanut products has increased steadily in India. Consumption of arecanut in India has increased from 2.50 lakh tonnes during 199192 to around 5.2 lakh tonnes in 2009-10 with an annual growth rate of around five per cent.
Considering the importance and growing demand for arecanut, there is a lot of scope for increasing the production of arecanut by increasing the productivity through adoption of improved technologies. In the process of horticultural development new farming technologies are considered as the prime mover. The horticultural technology is not accepted by the farmers completely in all aspects. As such there always appear to be a gap between the recommended technology by the scientists and its modified form at the 
farmer's level. The technology gap is thus the major problem towards the efforts for increasing horticultural production in the country.

After six decades of green revolution and with an appreciably improved extension services, the country is need to attain the goals of sustained economic growth in the agricultural sector. Now, the progress in agriculture depends on willingness and ability of farmers to use the new technology and required inputs. In this context, it is essential to understand the multidimensional behavior and socio-economic characteristics of the farmers for adoption of improved agricultural practices.

\section{Materials and Methods}

The study was conducted during the year 2015-16 in Uttara Kannada district of Karnataka. Sirsi, Siddapur and Yellapur talukas of Uttara Kannada District were selected for the study in the view of their highest share in area and the production in the district. From each taluka four villages were selected randomly.

Totally twelve villages and from each village fifteen arecanut growers were selected randomly to make the total sample of 180 . The ex-post-facto research design was used for the study. A pre-tested interview schedule was used to collect the data through personal interview method. The data collected were then tabulated and analyzed by using suitable statistical tools.

\section{Results and Discussion}

The perusal of the results in Table- 1 depicts that 7 variable out of 13 had a significant relationship with the technological gap of the arecanut growers and has discussed in details as follows.

\section{Age and technological gap}

The variable age was found to have nonsignificant relationship with technological gap of arecanut growers. Arecanut being highly remunerative crop might have induced the arecanut growers irrespective of young or old to take up some or all of the recommended practices for adoption. This might become the reason for non-significant relation with age and technological gap. The results are in line with the findings of Kudari (2014) who delineated the dominance of middle age among the sample farmers were in agreement with the present findings.

\section{Education and technological gap}

There was negative and significant relationship between education and technological gap of the arecanut growers. As education increases, technological gap decreases. Education exposes arecanut growers to more communication media or methods. Better perception and comprehension could be observed among well educated arecanut growers than others. Acquisition of formal education helps to interpret ideas in a rational manner resulting in better decision making. Thus, education provides a persistent reorientation to the arecanut growers, wherein they gradually understand science and innovations and ultimately reflecting on better adoption of practices.

Similar findings were observed in studies of Deepa et al., (2013) thatvariables like education, category of farmer, family type, family size, size of holding, material possession, social participation, production orientation, market orientation, risk orientation, mass media exposure, personal cosmopolite and personal localite have negative and significant relationship with technological gap. 


\section{Land holding and technological gap}

A glance at the results revealed that, land holding showed negative and highly significant relation with technological gap. It can be inferred that more area a person posses for cultivation, the lesser will be the technological gap. The arecanut growers with large land holding will have more opportunities and potentialities to try and adopt large number of technological innovations. As a result, it is quite possible that arecanut growers with large farm size show keen interest to know about new farm practices and will be more receptive to such ideas which in turn reflect on lesser technological gap. The results are in line with Sabi (2012) revealed that 35.83 per cent of farmers belonged medium land holding category (10-25.0 acres).

\section{Area under arecanut cultivation and technological gap}

The perusal of the results indicates that there was a non-significant relationship between area under arecanut cultivation and technological gap. This indicates that adoption of recommended cultivation practices of arecanut will not vary with the area devoted for arecanut cultivation. Arecanut is a major cash crop which influenced growers to adopt recommended practices irrespective of area under arecanut. This may reason to show non-significant relation with technological gap.

The results were in conformity with the results of Sunil (2015) that as high as 41.67 per cent of the progressive farmers and 38.33 per cent other farmers had medium area under sugarcane followed by 36.67 per cent of progressive farmers and a meagre percentage $(8.33 \%)$ of other farmers had high area under sugarcane cultivation.

\section{Experience in arecanut cultivation}

There was a non-significant relationship between experience in arecanut cultivation and technological gap. Arecanut is highly remunerative crop, this may have influence all the arecanut growers to adopt recommended practices irrespective of experience in arecanut cultivation. Hence the results are non- significant with technological gap. The findings of the study are supported by the study of Bheemudada (2015) who mentioned that respondents had medium level of farming experience.

\section{Family size and technological gap}

Family size showed non-significant relationship with technological gap. It indicates that larger the family size technological gap will not be reduced. There was no relationship between family size and technological gap. This may be due to irrespective of family size arecanut growers were getting high income because arecanut is a major cash crop and had remunerative prices in market which motivates arecanut growers to adopt technologies. Hence it showed non significant relationship. The findings are in line with Deepa et al., (2013) that variables like education, category of farmer, family type, family size, size of holding, material possession, social participation, production orientation, market orientation, risk orientation, mass media exposure, personal cosmopolite and personal localite have negative and significant relationship with technological gap.

\section{Annual income and technological gap}

Annual income showed non-significant relationship with technological gap. This can be inferred that if annual income of the respondents is high, then ability to adopt recommended technologies will not be high. 
The probable reason might be that, most of arecanut growers were investing more money on maintenance of arecanut plantation and family rather than adoption of technology. Hence annual income was found nonsignificant with technology gap of arecanut. This results are in line with Sanjota (2014).

\section{Extension contact and technological gap}

Extension contact was found to be highly significant relationship with technological gap of the arecanut growers. It is obvious that arecanut growers who are in constant contact with the extension personnel are likely to get more attention and guidance from them regarding the cultivation practices of crops which would further increase the technical know-how and adoption of recommended practices. This implies that the arecanut growers who are in contact with the extension personnel would have lesser technological gap and hence the result. The results are in agreement with findings of Shivalingaiah et al., (2012) that variables like farming experience, extension contact, social participation, risk orientation and scientific orientation were found to be highly significant at 0.01 per cent level with the adoption level.

\section{Mass media exposure and technological gap}

There existed a negative and highly significant relationship between mass media exposure and technological gap of arecanut growers. The higher levels of exposure to mass media would facilitate the individual to develop habits of gathering more information about innovations through television, newspaper, radio and farm magazines related to arecanut cultivation. Such individuals will be in readiness to accept the practices than others, who do not have exposure to mass media. In other words, exposure to mass media modernizes arecanut growers; make them more efficient in acquiring, retaining and evaluative the effective factors of adoption. Mass media also provides enormous opportunity for repeated exposure to new technology, motivating the arecanut growers to acquire and to take positive steps relevant for adoption of recommended cultivation practices. This view could be in accordance with Madhu (2010) that there existed a significant association between mass media participation and technological gap. The higher levels of exposure to mass media would facilitate the individual to develop habits of gathering more information about innovations through television, radio, newspaper and other literature related to turmeric cultivation.

\section{Economic motivation and technological gap}

There was a negative and highly significant relationship between the economic motivation and the technological gap of arecanut growers. It serves as an indicator of the arecanut growers orientation to excel in arecanut production and succeed in his activities. Further, the individual generally will have higher orientation towards scientific technology and competition. It also acts as an indicator of person's evaluative perception of activities with different dimensions such as practicability leading to rational decision making thus, it helps an individual to realize maximum economic profit from arecanut production. It also influences farmers to take correct decision at right time because growers were motivated economically. Thus, economic motivation has established negative and highly significant relationship with the technological gap. The results get support from the findings of Shivalingaiah et al., (2012) that variables like education, level of aspiration, cosmopoliteness, economic motivation and innovative proneness showed 
lesser level of significance at 0.05 per cent level.

\section{Scientific orientation and technological gap}

Scientific orientation was negative and highly significant relationship with technological gap of arecanut growers. It indicates that higher the scientific orientation lesser the technological gap and lower the scientific orientation larger the technological gap. It is obvious that arecanut growers who are adopting new methods of farming give better results than old methods and it helps an individual to realize maximum economic profit and higher yield in arecanut cultivation. The findings are supported by the studies of Ashokkumar (2011).

\section{Market orientation and technological gap}

The market orientation was found to have a negative and significant relationship with technological gap. The most important cause of market orientation is an underlying willingness to get good price by grading and storage of produce. It also serves as market news for the growers which help to fetch a good price for their produce and arecanut growers should grow those crops which have more market demand. Thus, market orientation must have established negative and significant relationship with technological gap. These findings are in conformity with Jadhav (2006) variables namely education, extension participation, innovative proneness and mass media participation was found to have negative and significant relationship with the technological gap. While, the variables age, orchard size, cosmopoliteness, risk orientation, economic motivation and market orientation showed positive but non significant relationship with technological gap in adoption of recommended mango cultivation practices.

Table.1 Relationship between technological gap and independent variables

\begin{tabular}{|c|l|c|}
\hline Sl. No. & \multicolumn{1}{|c|}{ Independent variables } & ' $\mathbf{r}$ ' value \\
\hline $\mathbf{1}$ & Age & 0.132 \\
\hline $\mathbf{2}$ & Education & $-0.187^{*}$ \\
\hline $\mathbf{3}$ & Land holding & $-0.295^{* *}$ \\
\hline $\mathbf{4}$ & Area under arecanut cultivation & 0.120 \\
\hline $\mathbf{5}$ & Experience in arecanut cultivation & 0.128 \\
\hline $\mathbf{6}$ & Family size & 0.133 \\
\hline $\mathbf{7}$ & Annual income & 0.130 \\
\hline $\mathbf{8}$ & Extension contact & $-0.201^{* *}$ \\
\hline $\mathbf{9}$ & Mass media exposure & $-0.209^{* *}$ \\
\hline $\mathbf{1 0}$ & Economic motivation & $-0.196^{* *}$ \\
\hline $\mathbf{1 1}$ & Scientific orientation & $-0.304^{* *}$ \\
\hline $\mathbf{1 2}$ & Market orientation & $-0.174^{*}$ \\
\hline $\mathbf{1 3}$ & Organization participation & 0.136 \\
\hline
\end{tabular}


Table.2 Multiple regression analysis of the independent variables with technological gap of arecanut growers

\begin{tabular}{|c|l|c|c|c|}
\hline $\begin{array}{c}\text { Sl. } \\
\text { No. }\end{array}$ & Independent variables & $\begin{array}{c}\text { Regression co- } \\
\text { efficient (b) }\end{array}$ & $\begin{array}{c}\text { Standard } \\
\text { error }\end{array}$ & 't' value \\
\hline $\mathbf{1}$ & Age & -0.131 & 0.073 & -1.798 \\
\hline $\mathbf{2}$ & Education & $-0.448^{* *}$ & 0.174 & -2.574 \\
\hline $\mathbf{3}$ & Land holding & $-0.732^{* *}$ & 0.170 & -4.306 \\
\hline $\mathbf{4}$ & $\begin{array}{l}\text { Area under arecanut } \\
\text { cultivation }\end{array}$ & 0.659 & 0.512 & 1.286 \\
\hline $\mathbf{5}$ & $\begin{array}{l}\text { Experience in arecanut } \\
\text { cultivation }\end{array}$ & $0.168^{*}$ & 0.080 & 2.092 \\
\hline $\mathbf{6}$ & Family size & 0.057 & 0.235 & 0.292 \\
\hline $\mathbf{7}$ & Annual income & $6.849 \mathrm{E}-7$ & 0.000 & 0.570 \\
\hline $\mathbf{8}$ & Extension contact & -0.016 & 0.123 & -0.131 \\
\hline $\mathbf{9}$ & Mass media exposure & $-0.332^{*}$ & 0.143 & -2.316 \\
\hline $\mathbf{1 0}$ & Economic motivation & $-0.265^{*}$ & 0.107 & -2.464 \\
\hline $\mathbf{1 1}$ & Scientific orientation & $-0.361^{* *}$ & 0.117 & -3.096 \\
\hline $\mathbf{1 2}$ & Market orientation & -0.282 & 0.213 & -1.320 \\
\hline $\mathbf{1 3}$ & Organization participation & -0.142 & 0.493 & -0.287 \\
\hline
\end{tabular}

\section{Organisation technological gap}

Organisation participation and technological gap found to have a non-significant relation with each other. This is because, irrespective of arecanut growers participation in organization they have adopt some recommended practices, which were simple and practicing from generation to generation. These practices also as simple as they did not require any technical guidance namely spraying of bordeaux mixture, mulching, application of lime, application of organic manures, etc., Easy availability of FYM from their own farm yard pit and high market price of the arecanut influencing the farmer to adopt technologies irrespective of participation in organizations so the results found non-significant relation with technological gap. The results are in line with the study conducted by Sabi (2012) reveals that majority of the respondents had low organizational participation (68.33\%), followed by high (17.50\%) and medium $(14.17 \%)$ organizational participation respectively.

Contribution of independent variable to technological gap of the arecanut growers

Technological gap in adoption of recommended cultivation practices had significant correlation with 7 out of 13 independent variables studied (Table-1). Further, the extent of contribution of these significant variables to the technological gap was analysed using multi linear regression. 
It could also be observed from Table 2 that the ' $F$ ' value $(F=5.969)$ obtained was significant at one per cent level indicating that all the independent variables put together contributed significant to the variation in the technological gap of arecanut growers. The coefficient of determination $\left(\mathrm{R}^{2}\right)$ was 0.564 , which revealed that 52.64 per cent of the variation in the technological gap of arecanut growers was together explained by all the independent variables selected for the study.

The results also revealed that the variables namely education, land holding, experience in arecanut cultivation, mass media exposure, economic motivation and scientific orientation were found to have significantly contributing to the variation in technological gap of the arecanut growers. Hence, these six variables could be considered as good predictors of variation in the technological gap in adoption of recommended cultivation practices by arecanut growers.

Further, 52.64 per cent of variation could be explained in the present study bythirteen independent variables, it is implied that there are other unidentified variables contributing to the variation in the technological gap of the arecanut growers were not included in the present study. Nevertheless, this study could identify the variables responsible for appreciable extent of variation in the technological gap of arecanut growers. The results are in line with Suil (2015).

The study concludes that it is essential to understand the multidimensional behavior and socio-economic characteristics of the farmers for adoption of improved agricultural practices which in turn reduces the technological gap. Variables like land holding, extension contact, mass media exposure, economic motivation, scientific orientation, education and market orientation had significant relationship with the technological gap of the arecanut growers. The regression analysis revealed that the selected independent variables put together explained 56.40 per cent of variation in technological gap of the arecanut growers. Variables such as age, area under arecanut cultivation, experience in arecanut cultivation, family size, annual income, organisation participation were non significantly related with technology gap of farmers. It was observed that large land holding and higher educational level would narrow down the technological gap. Hence, special attention needs to be given to illiterate farmers, farmers having low income, small land holdings farmers by educating them through demonstrations, trainings and use extension methodology like farmers field schools.

\section{References}

Ashokkumar, B., 2011, A study on entrepreneurial qualities and adoption behaviour of banana growers. $M$. Sc. (Agri.) Thesis, Univ. Agric. Sci., Dharwad, Karnataka, India.

Beemudada, A. B., 2015, Technological gap in ginger cultivation. M. Sc. (Agri.) Thesis, Univ. Agric. Sci., Dharwad, Karnataka, India.

Deepa, R., Bandyopadhyay, A. K. and Abhishek, G., 2013, Identification of technological gap in pineapple cultivation in some selected areas of West Bengal. International Journal of Science, Environment and Technology, Vol. 2 (3): $442-448$.

Jadhav, B. A., 2009, Technological gap in adoption of recommended practices of mango cultivation. M. Sc. (Agri.) Thesis, Univ. Agric. Sci., Dharwad, Karnataka, India.

Kudari, M. B. 2014, A study on perception of precision farming by the farmers. $M$. Sc. (Agri.) Thesis, Univ. Agric. Sci., Dharwad, Karnataka, India. 
Sabi, S., 2012, Knowledge and technological gap in wheat production. M. Sc. (Agri.) Thesis, Univ. Agric. Sci., Dharwad, Karnataka, India.

Shivalingaiah, Y. N., Reddy, S. K. M. And Desai, N., 2012, Yield gap, adoption pattern analysis and production constraints of coconut growers in
Karnataka. Karnataka J. Agric. Sci., 19 (2): 334-338.

Sunil, S. P., 2015, Analysis of improved cultivation practices of progressive sugarcane growers. M. Sc. (Agri.) Thesis, Univ. Agric. Sci., Dharwad, Karnataka, India.

\section{How to cite this article:}

Vinoda Shankara Naik and Patil, S.L. 2019. An Analysis of Relationship between Technological Gap and Socio-economic Characteristics of Arecanut Growers in Uttara Kannada District. Int.J.Curr.Microbiol.App.Sci. 8(02): 1243-1250. doi: https://doi.org/10.20546/ijcmas.2019.802.145 